(c) American Dairy Science Association, 2003.

\title{
Inactivation of Spores of Bacillus cereus in Cheese by High Hydrostatic Pressure with the Addition of Nisin or Lysozyme
}

\author{
Tomás J. López-Pedemonte, Artur X. Roig-Sagués, Antonio J. Trujillo, \\ Marta Capellas, and Buenaventura Guamis \\ Centre Especial de Recerca \\ Planta de Tecnologia dels Aliments, CeRTA, XiT, \\ Departament de Ciència Animal i dels \\ Aliments, Facultat de Veterinària, Universitat Autònoma de Barcelona, \\ 08193 Bellaterra, Spain
}

\section{ABSTRACT}

The objective of this work was to study high hydrostatic pressure (HHP) inactivation of spores of Bacillus cereus ATCC 9139 inoculated in model cheeses made of raw milk, together with the effects of the addition of nisin or lysozyme. The concentration of spores in model cheeses was approximately 6 - $\log _{10} \mathrm{cfu} / \mathrm{g}$ of cheese. Cheeses were vacuum packed and stored at $8^{\circ} \mathrm{C}$. All samples except controls were submitted to a germination cycle of $60 \mathrm{MPa}$ at $30^{\circ} \mathrm{C}$ for $210 \mathrm{~min}$, to a vegetative cells destruction cycle of 300 or $400 \mathrm{MPa}$ at $30^{\circ} \mathrm{C}$ for $15 \mathrm{~min}$, or to both treatments. Bacillus cereus counts were measured $24 \mathrm{~h}$ and $15 \mathrm{~d}$ after HHP treatment. The combination of both cycles improved the efficiency of the whole treatment. When the second pressure-cycle was of $400 \mathrm{MPa}$, the highest inactivation $(2.4 \pm 0.1$ $\log _{10} \mathrm{cfu} / \mathrm{g}$ ) was obtained with the presence of nisin (1.56 $\mathrm{mg} / \mathrm{L}$ of milk), whereas lysozyme $(22.4 \mathrm{mg} / \mathrm{L}$ of milk) did not increase sensitivity of the spores to HHP. For nisin ( 0.05 and $1.56 \mathrm{mg} / \mathrm{L}$ of milk), no significant differences were found between counts at $24 \mathrm{~h}$ and $15 \mathrm{~d}$ after treatment. Considering that mesophilic spore counts usually range from 2.6 to $3.0 \log _{10} \mathrm{cfu} / \mathrm{ml}$ in raw milk, HHP at mild temperatures with the addition of nisin may be useful for improving safety and preservation of soft curd cheeses made from raw milk.

(Key words: Bacillus cereus, high pressure, lysozyme, nisin)

Abbreviation key: $\mathbf{G}=$ germination treatment, $\mathbf{H H P}$ = high hydrostatic pressure, $\mathbf{L}=$ lysozyme series of experiments, $\mathbf{N 1}=$ minor dose of nisin treatment, $\mathbf{N} \mathbf{2}=$ higher dose of nisin series of experiments.

Received February 13, 2003.

Accepted May 22, 2003.

Corresponding author: A. X. Roig-Sagues; e-mail: ArturXavier. Roig@uab.es.

\section{INTRODUCTION}

Bacillus cereus has been reported to be a common contaminant of raw milk. It seems impossible to prevent its presence in milk samples, because spores adhere to stainless steel surfaces even after cleaning, due to their high hydrophobicity, low surface charge, and long appendages. The organism is commonly lecithinase-positive; therefore, it can attack the intact milk fat globule membrane and cause bitterness or sweet curdling (Andersson et al., 1995). The pathogenic nature of B. cereus adds the risk of two possible clinical forms of food poisoning. Three different enterotoxins and one emetic toxin are produced, even during growth in milk at refrigerated temperatures. The extracellular diarrhoeagenic enterotoxins are inactivated by temperature $\left(56^{\circ} \mathrm{C}\right)$ and proteases and an emetic type nonprotein toxin that is extremely stable to heat and $\mathrm{pH}$ while being resistant to trypsin and pepsin (Granum and Lund, 1997). Milk and dairy products have been implicated in both types of intoxication (Meer et al., 1991; Andersson et al., 1995).

High hydrostatic pressure (HHP) is generally effective at reducing most vegetative bacteria, yeasts, and molds between 300 and $700 \mathrm{MPa}$, but bacterial spores have demonstrated resistance to more than $1000 \mathrm{MPa}$ (Smelt, 1998). Recommended treatments for direct destruction of spores to obtain shelf-stable, low-acid foods, involve two consecutive 1-min cycles of at least $621 \mathrm{MPa}$ starting around $80^{\circ} \mathrm{C}$ and reaching final temperatures equal to or higher than $105^{\circ} \mathrm{C}$ (Meyer et al., 2000). Alternatively, bacterial spore inactivation can be achieved in two steps: first stimulating its germination by applying pressures of 50 to $300 \mathrm{MPa}$ and then killing germinated cells by using relatively mild heat and pressure treatments (Gould et al., 1970; Sojka and Ludwig, 1994). However, a fraction of spores may survive.

It has been shown that efficiency of HHP against spores is enhanced when used in conjunction with other treatments including mild heat and antimicrobial agents (Shearer, et al., 2000). Hurdle technology relies 
on the synergistic combination of different moderate factors to improve food safety, compensating for individual process limitations and minimizing the use of extreme levels of any one treatment. As pressurization may inflict sublethal injury in both gram-positive and gram-negative bacterial cells, it makes them more susceptible to antibacterial compounds such as nisin or lysozyme among others (Kalchayanand et al., 1998; Masschalk et al., 2001). In Mató cheese, combining nisin with high pressure improved the effect of the latter on spores and aerobic mesophilic populations $(\mathrm{Ca}-$ pellas et al., 2000).

Traditional soft curd cheeses cannot be submitted to temperatures above $40^{\circ} \mathrm{C}$. The risk of causing food poisoning increases if cheeses are made from raw milk, and the safety of curing procedures alone as the main pathogen control step in cheese making is currently under review (Altekruse et al., 1998). Several studies with food as the assay medium have proved the influence of the food matrix on microbial sensitivity to pressure (Patterson et al., 1998; Capellas et al., 2000; Gervilla et al., 2000). Model cheeses are closer to real cheese than slurries and tube tests. They offer the possibility of testing single bacterial strains in a real washed-curd cheese environment (Ur-Rehman et al., 2001).

The objective of this work was to study the influence of HHP (one- vs. two-cycle treatments) on the inactivation of spores of $B$. cereus ATCC 9139 inoculated in model cheeses made from raw milk under controlled microbiological conditions. The possible increase of sensitivity to nisin or lysozyme produced by HHP was also studied.

\section{MATERIALS AND METHODS}

\section{Preparation of Inocula of $B$. cereus Spores}

A young culture $\left(18 \mathrm{~h}, 37^{\circ} \mathrm{C}\right)$ of $B$. cereus ATCC 9139 (CECT 5144; Colección Española de Cultivos Tipo) in brain heart infusion (Oxoid, Unipath Ltd., UK) was spread plated on tryptone soy agar (Oxoid) containing (per liter) $0.05 \mathrm{mg}$ of manganese and incubated for $3 \mathrm{~d}$ at $37^{\circ} \mathrm{C}$ until 80 to $90 \%$ sporulation was obtained. Spores were harvested by flooding the agar surface with $0.85 \% \mathrm{NaCl}$ and scraping it with sterile glass balls. This suspension was heated for $10 \mathrm{~min}$ at $80^{\circ} \mathrm{C}$ and quickly cooled to $5^{\circ} \mathrm{C}$. It was then centrifuged for 20 min at $4000 \times g$ at $5^{\circ} \mathrm{C}$ and washed twice with sterile distilled water. Finally the spores were resuspended in $0.85 \% \mathrm{NaCl}$ and stored at $4^{\circ} \mathrm{C}$. Bacillus cereus spore counts were approximately $8-\log _{10} \mathrm{cfu} / \mathrm{ml}$.

\section{Manufacture of Model Cheeses}

Model washed-curd cheeses were manufactured under controlled microbiological conditions following a modification of the procedure described by Hynes et al. (2000). Raw milk was collected from a local farm, placed inside a sterile tank, and transported under refrigerated conditions in less than $2 \mathrm{~h}$ to the laboratory. Milk was brought to $31^{\circ} \mathrm{C}$ in a water bath. Strains of Lactococcus lactis subsp. lactis and Lactococcus lactis subsp. cremoris (Ezal MAO 11, Rhodia Iberia S.A., Madrid, Spain), which do not produce bacteriocins, were added as starter of $2 \%(\mathrm{vol} / \mathrm{vol})$, together with $0.01 \%(\mathrm{vol} / \mathrm{vol})$ of a 35\% (wt/vol) calcium chloride solution (Arroyo, Santander, Spain) to improve coagulation. A $0.02 \%$ (vol/ vol) liquid rennet extract of calf origin $(520 \mathrm{mg} / \mathrm{L}$ of active chymosin, Arroyo, Santander, Spain) was used as coagulating agent. Milk was poured in previously autoclaved long-necked centrifuge bottles of $225 \mathrm{ml}$ containing $B$. cereus inocula (except blanks). Coagulation took place at $31^{\circ} \mathrm{C}$. After $45 \mathrm{~min}$, curds were gently cut with sterile stainless steel tools and heated for $15 \mathrm{~min}$ at $37^{\circ} \mathrm{C}$. About $40 \%$ of whey was discarded and replaced by sterile water. Bottles were centrifuged at $7000 \times g$ for $40 \mathrm{~min}$ at room temperature. Then they were kept in the water bath at $37^{\circ} \mathrm{C}$ until $\mathrm{pH}$ reached 5.5. The whey was discarded, and $20 \%$ sterile brine ( $200 \mathrm{~g}$ of $\mathrm{NaCl}$ per liter of tap water) was added directly inside the bottle. After 15 min, brine was removed and cheeses were taken out from the bottles and dried with sterile paper. All of these conditions had been previously adjusted to obtain $55 \%$ of DM, $1.5 \%$ salt-in-moisture content, and a final $\mathrm{pH}$ around 5. Inoculum density of spores was approximately $6-\log _{10} \mathrm{cfu} / \mathrm{g}$ of cheese. Model cheeses of approximately $23 \mathrm{~g}$ were vacuum packed in plastic bags (Cryovac Packaging, Sant Boi de Llobregat, Spain) and stored at $8^{\circ} \mathrm{C}$ for $15 \mathrm{~d}$.

\section{Addition of Lysozyme}

In one experiment series, egg white lysozyme (Larbus s.a., Madrid, Spain) was added to milk $(22.4 \mathrm{mg} / \mathrm{L})$ and then homogenized before pouring it into centrifuge bottles.

\section{Addition of Nisin}

Two series of experiments were carried out incorporating nisin (Nisaplin, Applin \& Barret Ltd., Towbridge, UK) using two different doses: 0.05 and 1.56 $\mathrm{mg} / \mathrm{L}$ of milk. Nisin was added and homogenized before pouring milk into centrifuge bottles.

\section{HHP Treatments}

Samples were pressurized $24 \mathrm{~h}$ after manufacture by using discontinuous HHP equipment (ALSTOM, Nantes, France). The pressure chamber and the pres- 
Table 1. High hydrostatic pressure (HHP) treatments applied to all four series of experiments and their codification.

\begin{tabular}{llll}
\hline & & \multicolumn{2}{c}{ HHP treatments } \\
\cline { 3 - 4 } Series of experiments & Code & Conditions & Code \\
\hline & & $60 \mathrm{MPa} / 210 \mathrm{~min} / 30^{\circ} \mathrm{C}$ & $\mathrm{G}^{1}$ \\
Without additives & $\mathrm{WA}$ & $300 \mathrm{MPa} / 15 \mathrm{~min} / 30^{\circ} \mathrm{C}$ & 300 \\
Nisin $0.05 \mathrm{mg} / \mathrm{L}$ of milk & $\mathrm{N} 1$ & $400 \mathrm{MPa} / 15 \mathrm{~min} / 30^{\circ} \mathrm{C}$ & 400 \\
Nisin $1.56 \mathrm{mg} / \mathrm{L}$ of milk & $\mathrm{N} 2$ & $60 \mathrm{MPa} / 210 \mathrm{~min} / 30^{\circ} \mathrm{C}+300 \mathrm{Mpa} / 15 \mathrm{~min} / 30^{\circ} \mathrm{C}$ & $\mathrm{G}+300$ \\
Lysozyme $22.4 \mathrm{mg} / \mathrm{L}$ of milk & $\mathrm{L}$ & $60 \mathrm{MPa} / 210 \mathrm{~min} / 30^{\circ} \mathrm{C}+400 \mathrm{Mpa} / 15 \mathrm{~min} / 30^{\circ} \mathrm{C}$ & $\mathrm{G}+400$ \\
\hline${ }^{1}$ Germination treatment. & & &
\end{tabular}

surizing liquid inside were held at the appropriate temperature $\left(30^{\circ} \mathrm{C}\right.$, monitored with a thermocouple) by circulating hot water through a coil. Before HHP treatments, cheeses were placed for 15 min inside a water bath to reach $30^{\circ} \mathrm{C}$. Table 1 shows all four series of experiments performed with HHP alone and in combination with nisin or lysozyme.

\section{Microbiological Analysis}

Microbiological cheese analysis was performed at 24 $\mathrm{h}$ and at $15 \mathrm{~d}$ after treatment, homogenizing $10 \mathrm{~g}$ of sample in $90 \mathrm{ml}$ of buffered peptone water (Oxoid), for $1 \mathrm{~min}$ in an electromechanical blender (BagMixer, Interscience, France). Decimal dilutions in buffered peptone water were surface spread on $B$. cereus selective agar (Oxoid) and incubated at $37^{\circ} \mathrm{C}$ for 18 to $24 \mathrm{~h}$ following the instructions of the manufacturer. Blank samples (not inoculated with spores) were included to assess the presence of naturally occurring $B$. cereus in raw milk and to correct counts if necessary. Inoculated model cheeses without additives and not submitted to any HHP treatment were called controls. Cheeses with additives and not submitted to HHP were called lysozyme controls and nisin controls, respectively. Lethality was calculated comparing control samples with treated ones.

\section{Statistical Analysis}

Each HHP experiment was run three separate times with duplicate analysis in each replicate. ANOVA of SPSS 10.0 for Windows (SPSS Inc, Chicago, IL) was used. Tukey and Student-Newman-Keuls tests were used to obtain paired comparisons among sample means. Level of significance was $P<0.05$.

\section{RESULTS AND DISCUSSION}

\section{Effect of 300 and 400 HHP Single Treatments on $B$. cereus}

The application of a one-step treatment of HHP to model cheeses resulted in a small amount of inactiva- tion, which did not reach $1-\log _{10}$ reduction of B. cereus (Figure 1). This agrees with previous data (Meyer et al., 2000; McClements et al., 2001). Raso et al. (1998) studied germination and inactivation of $B$. cereus spores in saline buffer supplemented with sucrose. When $B$. cereus spores were obtained at $37^{\circ} \mathrm{C}$ and treatments of $250 \mathrm{MPa}$ for $15 \mathrm{~min}$ at $25^{\circ} \mathrm{C}$ were applied, they found that although some germination took place while $\mathrm{pH}$ and water activity increased, no inactivation occurred at any $\mathrm{pH}$ between 3.5 and 7.8 combined with water activities between 0.92 and 1.00 . This is similar to results obtained in our work for treatments 300 and 400, considering that $\mathrm{pH}$ and water activity of model cheeses lie between the values tested by them.

\section{Effect of HHP Treatments with Germinative Cycle on B. cereus}

Because traditional soft curd cheeses cannot be submitted to temperatures above $40^{\circ} \mathrm{C}$ and based on surveys in which two-step treatments at mild temperatures were found to be best suited to initiate germination and then inactivate spores (Sojka and Ludwig, 1994; Capellas et al., 2000), the influence of one- vs. two-cycle HHP treatments (300 or $400 \mathrm{MPa}$ vs. $60+$ 300 or $60+400 \mathrm{MPa}$ ) at $30^{\circ} \mathrm{C}$ was studied.

When comparing lethalities obtained for treatments with or without the germinative step (Figure 1), it is clear that the addition of this first cycle at mild temperature and low pressure improved the efficiency of the whole treatment. In germination treatment alone $(\mathbf{G})$ and in both two-step treatments $(\mathrm{G}+300$ and $\mathrm{G}+400)$, mean lethality seemed to increase with pressure, although differences were not statistically significant.

Sojka and Ludwig (1994) have previously worked applying two-step HHP treatments to Bacillus subtilis spores. They proposed a treatment of $60 \mathrm{MPa}$ for 210 min to initiate $B$. subtilis spore germination in an aqueous solution, followed by $500 \mathrm{MPa}$ for $15 \mathrm{~min}$ to inactivate germinated cells. The reduction obtained was of $6-\log _{10}$ at $40^{\circ} \mathrm{C}$. In the present work, the maximum reduction obtained without additives was (1.6 \pm 0.3$)$ $\log _{10}$ of $B$. cereus spores for $\mathrm{G}+400$ treatment, which 


\section{All Series}

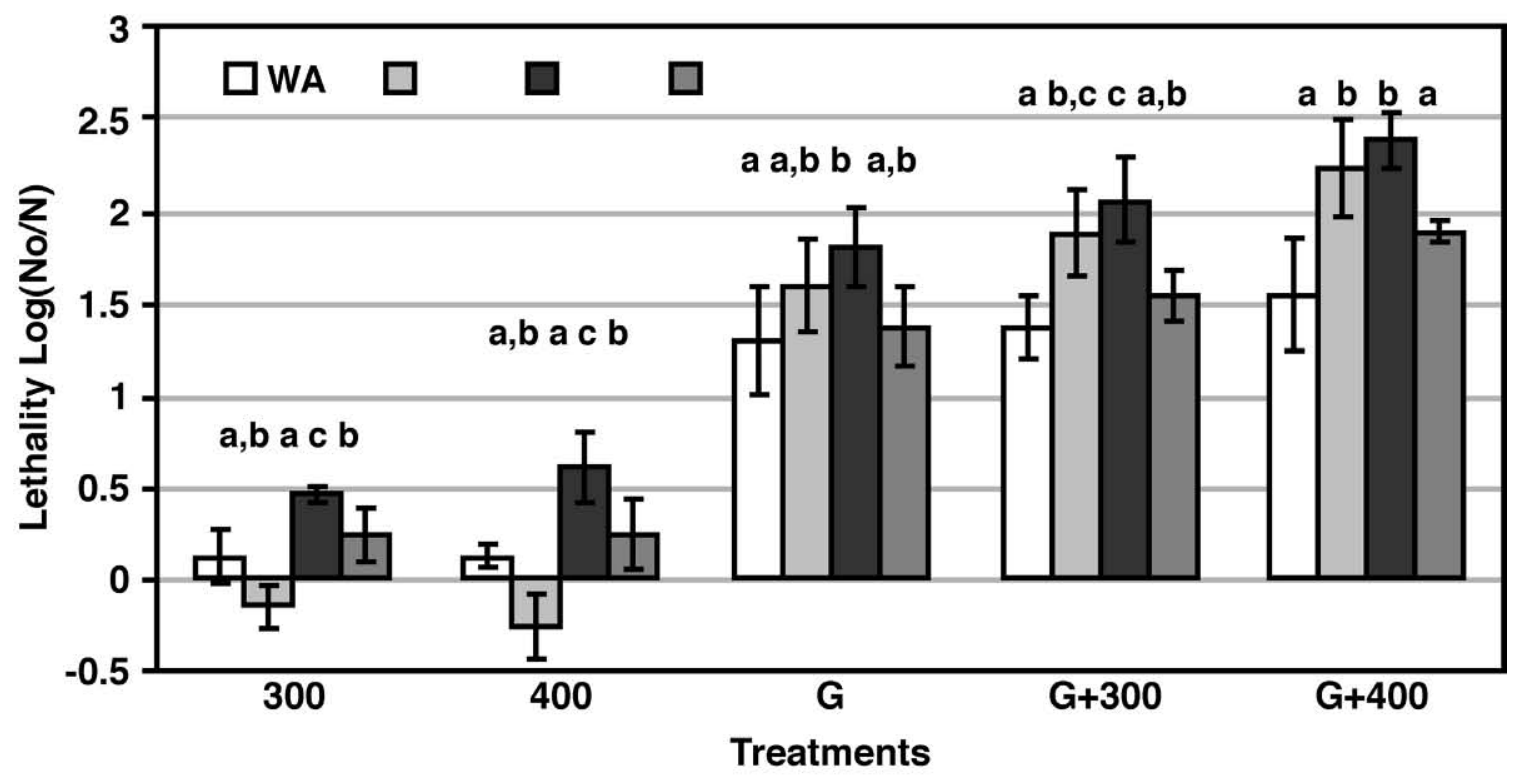

WA Series

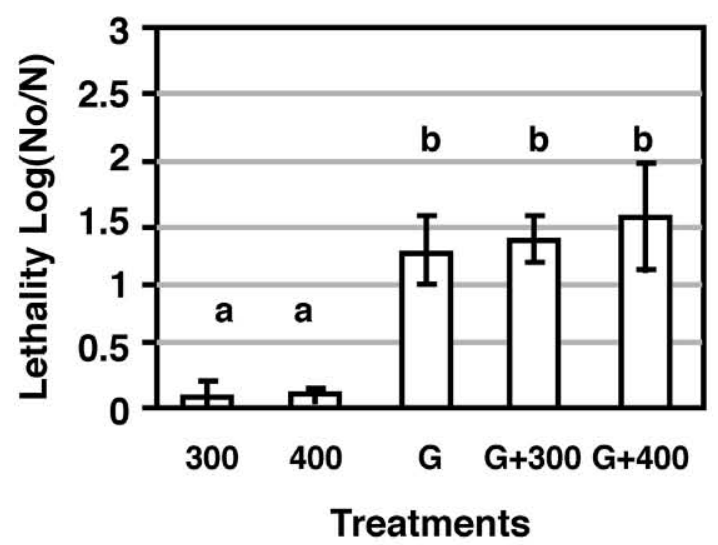

N1 Series

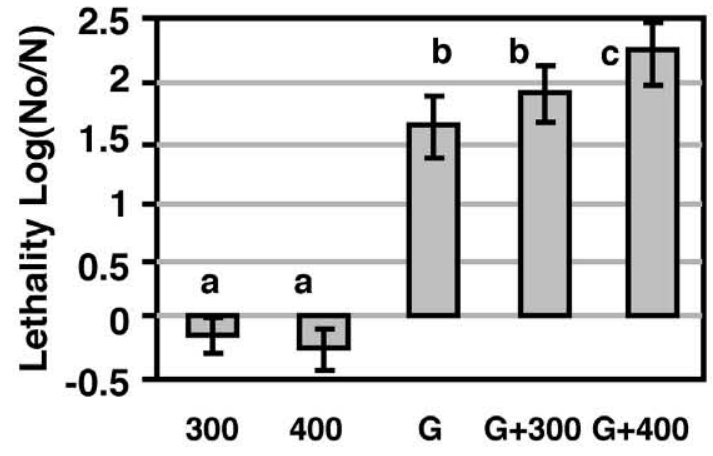

Treatments
L Series

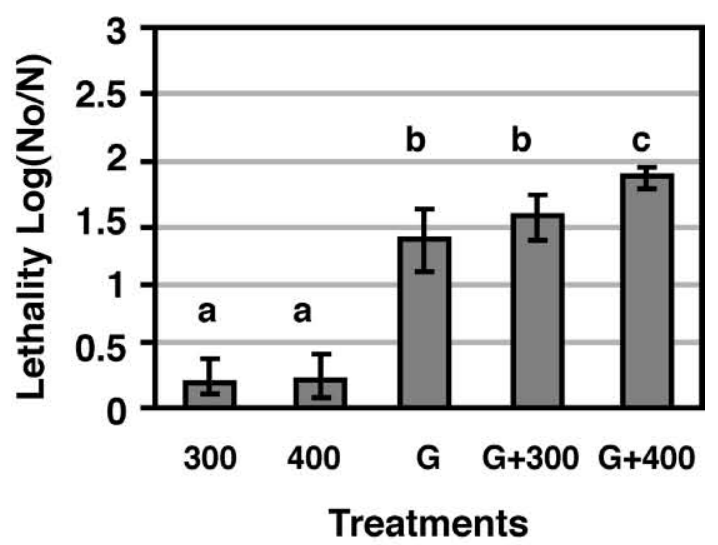

N2 Series

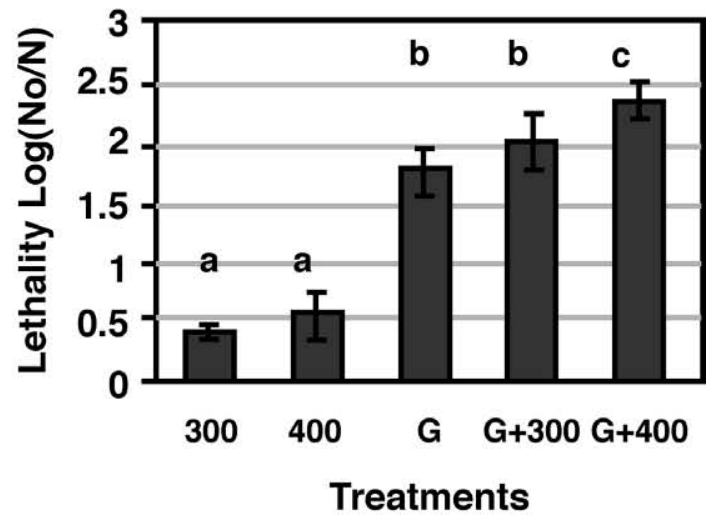

Figure 1. Mean lethality of Bacillus cereus \pm confidence interval (No and N stand for initial and final counts of $B$. cereus). Comparison of each treatment for all series of experiments and comparison between different treatments for each particular series of experiments. In all series graphics, for each treatment, column means with different superscript differ $(P<0.05)$. In without additives (WA), lysozyme (L), minor dose of nisin (N1), and higher dose of nisin (N2) Series graphics, column means with different superscripts differ $(P<0.05)$. 
is indeed lower. This is probably because they worked with aqueous solutions at higher temperatures and higher final pressures.

Capellas et al. (2000) have worked with B. subtilis spores in Mató cheese, applying the same pressure treatment at different temperatures. At $40^{\circ} \mathrm{C}$ they found a lethality value of $4.9-\log _{10}$ of $B$. subtilis spores, whereas at $25^{\circ} \mathrm{C}$ reduction was of $2.7-\log _{10}$. The inferior reduction values obtained in our work may be a consequence of applying $100 \mathrm{MPa}$ less (400 MPa) in the second cycle. In addition, cheese characteristics were different. The influence of substrate on pressure sensitivity of bacteria has already been stated (Jaquette and Beuchat, 1998; Patterson, 1998). This may explain the lower lethality values obtained in our work even though B. subtilis seems to be more pressure resistant than B. cereus (Nakayama et al. 1996; Meyer et al., 2000; Moerman et al., 2001). Pressure-induced germination proceeds faster at neutral $\mathrm{pH}$ if pressure is between 50 and $300 \mathrm{MPa}$ (Hauben et al., 1997). Model cheeses have a $\mathrm{pH}$ of around 5; this may also have caused decreased lethality values. Other factors such as strain within a species and stage of growth can also affect sensitivity of microorganisms to high pressure (Alpas et al., 1999; McClements et al., 2001).

\section{Effects of Additives on B. cereus Control Samples}

No significant differences were found between counts of controls and nisin or lysozyme controls (data not shown). The use of additives alone does not seem to affect $B$. cereus spores in model cheeses.

\section{Effect of 300 and 400 HHP Single Treatments and Additives on $B$. cereus}

For treatments 300 and 400 , the addition of lysozyme (L) or a minor dose of nisin (N1) did not improve the efficacy of HHP alone. On the contrary, experiments with the higher dose of nisin (N2) achieved a significant increase compared with without aditives, N1, and L series, although they were never higher than $1-\log _{10}$ reduction of $B$. cereus. The influence of both additives was hardly useful under these conditions.

\section{Effect of HHP with Previous Germinative Cycle and Additives on B. cereus}

When the germinative cycle alone was applied, N1 and N2 series values were not statistically different.

The addition of the second pressure cycle improved the efficacy of additives, as seen in lethality values. Counts of control samples and nisin control samples did not differ, so synergism between HHP and nisin is clearly observed. In particular, the germinating process may increase permeability of the spore coat. In this way, HHP facilitates the access of additives to germinated cell cytoplasmic membrane (Masschalk et al., 2001).

In both two-step treatments, lethalities obtained for $\mathrm{N} 1$ and N2 series were indeed significantly higher than without additives series. In $\mathrm{G}+400$ treatment, N2 series had the highest inactivation, although not statistically different from $\mathrm{N} 1$ series. It seems as if for these conditions, the higher dose of nisin was incapable of increasing synergism with HHP. Lethality values for this bacteriocin were in all cases higher than those for lysozyme. The effect of nisin against $B$. cereus is more pronounced as $\mathrm{pH}$ becomes more acidic (Jaquette and Beuchat, 1998). The $\mathrm{pH}$ of optimum activity for both additives is around 5, as it is in model cheeses, so in this case $\mathrm{pH}$ does not seem to be especially benefiting the activity of one additive over the other. However, the expected increase in sensitivity of $B$. cereus to lysozyme because of HHP turned out to be not significant enough to differentiate lethalities of $\mathrm{L}$ series from without additives ones.

\section{Comparison of 24-h and 15-d B. cereus Counts}

Processed samples were given an incubation period at $8^{\circ} \mathrm{C}$ of $15 \mathrm{~d}$ and then plate-counted to verify whether growth conditions obtained after HHP persisted. This 15-d period was chosen to allow surviving spores and cells to repair and grow. Comparison of $B$. cereus counts can be seen in Table 2 .

Most control samples experienced significant growth after $15 \mathrm{~d}$ at $8^{\circ} \mathrm{C}$. This might be explained by the ability of B. cereus to grow at $8^{\circ} \mathrm{C}$ (Jaquette and Beuchat, 1998) and by its mechanisms of resistance to nisin and lysozyme. Increments were also observed in many counts of $B$. cereus for treatments 300,400 , and $G$ at $d 15$. As well as in controls, the psychrotrophic nature of the remaining bacteria may be responsible for that increment. The presence of sublethally damaged organisms that may be able to repair and grow after a longer incubation period could also contribute (Smelt, 1998).

The germinative cycle alone was not able to ensure 15-d persistency of reductions for all series. On the contrary, in treatments $\mathrm{G}+300$ and $\mathrm{G}+400$ no statistical differences were found for without additives, N1, and N2 series between $24-\mathrm{h}$ and 15 -d counts. Thus, the second pressure cycle becomes essential to preserve the reductions seen in 24 -h counts for $15 \mathrm{~d}$ at $8^{\circ} \mathrm{C}$.

In $\mathrm{L}$ series for $\mathrm{G}+300$ and $\mathrm{G}+400$ treatments, 15 d counts were statistically higher than 24-h counts. This is another reason for choosing nisin over lysozyme as a preservative agent to be used with HHP. 
Table 2. Comparison of 24-h and 15-d Bacillus cereus counts in model cheeses stored at $8^{\circ} \mathrm{C}$ for all series of experiments. ${ }^{1}$

\begin{tabular}{|c|c|c|c|c|c|c|c|c|c|}
\hline \multirow[b]{2}{*}{ Samples } & \multicolumn{4}{|c|}{ B. cereus counts (log cfu/g) } & \multirow[b]{2}{*}{ Samples } & \multicolumn{4}{|c|}{ B. cereus counts $(\log \mathrm{cfu} / \mathrm{g})$} \\
\hline & $\begin{array}{l}\text { Day } 1 \\
(\mathrm{n}=6)\end{array}$ & $\mathrm{SE}$ & $\begin{array}{l}\text { Day } 15 \\
(\mathrm{n}=6)\end{array}$ & $\mathrm{SE}$ & & $\begin{array}{l}\text { Day } 1 \\
(\mathrm{n}=6)\end{array}$ & $\mathrm{SE}$ & $\begin{array}{l}\text { Day } 15 \\
(\mathrm{n}=6)\end{array}$ & $\mathrm{SE}$ \\
\hline WA series & & & & & N2 series & & & & \\
\hline Control & $6.05^{\mathrm{a}}$ & 0.19 & $6.50^{\mathrm{b}}$ & 0.13 & $\begin{array}{l}\text { Control } \\
\text { Nisin }\end{array}$ & $6.40^{\mathrm{a}}$ & 0.17 & $6.67^{\mathrm{b}}$ & 0.18 \\
\hline & & & & & control 2 & $6.17^{\mathrm{a}}$ & 0.12 & $6.63^{b}$ & 0.18 \\
\hline 300 & $5.82^{\mathrm{a}}$ & 0.11 & $6.28^{\mathrm{b}}$ & 0.10 & 300 & $5.71^{\mathrm{a}}$ & 0.10 & $6.09^{\mathrm{a}}$ & 0.30 \\
\hline 400 & $5.82^{\mathrm{a}}$ & 0.07 & $6.11^{\mathrm{a}}$ & 0.17 & 400 & $5.57^{\mathrm{a}}$ & 0.06 & $6.27^{\mathrm{b}}$ & 0.28 \\
\hline $\mathrm{G}$ & $4.77^{\mathrm{a}}$ & 0.07 & $4.99^{b}$ & 0.04 & $\mathrm{G}$ & $4.37^{\mathrm{a}}$ & 0.21 & $4.88^{\mathrm{b}}$ & 0.17 \\
\hline $\mathrm{G}+300$ & $4.58^{\mathrm{a}}$ & 0.19 & $4.95^{\mathrm{a}}$ & 0.08 & $G+300$ & $4.12^{\mathrm{a}}$ & 0.23 & $4.32^{\mathrm{a}}$ & 0.24 \\
\hline $\mathrm{G}+400$ & $4.39^{\mathrm{a}}$ & 0.27 & $4.74^{\mathrm{a}}$ & 0.10 & $\mathrm{G}+400$ & $3.78^{\mathrm{a}}$ & 0.17 & $4.22^{\mathrm{a}}$ & 0.22 \\
\hline N1 series & & & & & L series & & & & \\
\hline Control & $6.06^{\mathrm{a}}$ & 0.06 & $6.29^{b}$ & 0.13 & Control & $6.51^{\mathrm{a}}$ & 0.11 & $6.99^{b}$ & 0.06 \\
\hline Nisin & & & & & Lysozyme & & & & \\
\hline control 1 & $6.17^{\mathrm{a}}$ & 0.09 & $6.37^{\mathrm{b}}$ & 0.12 & control & $6.42^{\mathrm{a}}$ & 0.14 & $6.94^{\mathrm{b}}$ & 0.03 \\
\hline 300 & $6.15^{\mathrm{a}}$ & 0.03 & $5.74^{\mathrm{b}}$ & 0.02 & 300 & $6.18^{\mathrm{a}}$ & 0.08 & $6.33^{\mathrm{a}}$ & 0.09 \\
\hline 400 & $6.27^{\mathrm{a}}$ & 0.07 & $6.07^{\mathrm{a}}$ & 0.09 & 400 & $6.18^{\mathrm{a}}$ & 0.04 & $6.26^{\mathrm{a}}$ & 0.05 \\
\hline $\mathrm{G}$ & $4.42^{\mathrm{a}}$ & 0.08 & $4.87^{\mathrm{b}}$ & 0.07 & $\mathrm{G}$ & $5.05^{\mathrm{a}}$ & 0.04 & $5.39^{\mathrm{b}}$ & 0.07 \\
\hline $\mathrm{G}+300$ & $4.14^{\mathrm{a}}$ & 0.07 & $4.15^{\mathrm{a}}$ & 0.12 & $G+300$ & $4.88^{\mathrm{a}}$ & 0.09 & $5.09^{\mathrm{b}}$ & 0.05 \\
\hline$G+400$ & $3.79^{\mathrm{a}}$ & 0.06 & $3.92^{\mathrm{a}}$ & 0.06 & $G+400$ & $4.53^{\mathrm{a}}$ & 0.12 & $5.06^{\mathrm{b}}$ & 0.05 \\
\hline
\end{tabular}

${ }^{\mathrm{a}, \mathrm{b}}$ Column means within d 1 and d 15 category, for each series, with different superscripts differ $(P<$ $0.05)$.

${ }^{1} \mathrm{G}=$ germination treatment, $300=300 \mathrm{Mpa}, 400=400 \mathrm{Mpa} . \mathrm{WA}=$ without additives; $\mathrm{N} 1=$ minor dose of nisin; N2 = higher dose of nisin; L = lysozyme.

\section{Safety Implications}

The ability of psychrotrophic $B$. cereus spores to survive thermal pasteurization and subsequently grow in foods held at refrigerated temperatures is of public concern (Jaquette and Beuchat, 1998). The maximum reduction obtained $\left(2.4 \pm 0.1-\log _{10} \mathrm{cfu} / \mathrm{g}\right)$ may seem insuficient to assure safety of cheeses. However, initial load in our model cheeses is fairly high (more than $6-\log _{10}$ cfu/g) and, after applying both pressure cycles, total levels obtained were around $4-\log _{10} \mathrm{cfu} / \mathrm{g}$. It seems the number of viable cells or spores required for causing enteric intoxication varies between $5-\log _{10}$ and $8-\log _{10}$ $\mathrm{cfu} / \mathrm{g}$ of food. In most cases, the infective dose quoted is around $6-\log _{10} \mathrm{cfu} / \mathrm{g}$, although some strains of $B$. cereus might be capable of producing food poisoning at counts as low as 3 or $4-\log _{10} \mathrm{cfu} / \mathrm{g}$ (Granum and Lund, 1997). Moreover, in raw milk, mesophilic spore counts usually range from 2.6 to $3.0-\log _{10} \mathrm{cfu} / \mathrm{ml}$, and between these values the fraction corresponding to $B$. cereus varies with farms and seasons (White, 2000). Considering all these facts, in cheeses made from raw milk, HHP at mild temperatures together with the addition of nisin may be useful for improving its safety and preservation.

\section{ACKNOWLEDGMENTS}

The authors acknowledge the financial support received from the research project CAL-00-005-C2-1 (In- stituto Nacional de Investigación y Tecnología Agraria y Alimentaria) and the grant given to Tomás J. López by the Agencia Española de Cooperación Internacional. We also thank the Colección Española de Cultivos Tipo for providing the strain of $B$. cereus.

\section{REFERENCES}

Alpas, H., N. Kalchayanand, F. Bozoglu, A. Sikes, C. P. Dunne, and B. Ray. 1999. Variation in resistance to hydrostatic pressure among strains of food-borne pathogens. Appl. Environ. Microbiol. 65:4284-4251.

Altekruse, S. F., B. T. Babagaleh, J. C. Mowbray, N. H. Bean, and M. E. Potter. 1998. Cheese-associated outbreaks of human illness in the United States, 1973 to 1992: Sanitary manufacturing practices protect consumers. J. Food Prot. 61:1405-1407.

Andersson, A., U. Rönner, and P. E. Granum. 1995. What problems does the food industry have with the spore-forming pathogens Bacillus cereus and Clostridium perfringens? Int. J. Food Microbiol. 28:145-155.

Capellas, M., M. Mor-Mur, R. Gervilla, J. Yuste, and B. Guamis. 2000. Effect of high pressure combined with mild heat or nisin on inoculated bacteria and mesophiles of goats' milk fresh cheese. Food Microbiol. 17:633-641.

Gervilla, R., V. Ferragut, and B. Guamis. 2000. High pressure inactivation of microorganisms inoculated into ovine milk of different fat contents. J. Dairy Sci. 83:674-682.

Granum, E., and T. Lund. 1997. Bacillus cereus and its food poisoning toxins. FEMS Microbiol. Lett. 157:223-228.

Hauben, K. J. A., D. H. Bartlett, C. C. F. Soontjens, K. Cornelis, E. Y. Wuytack, and C. W. Michiels. 1997. Escherichia coli mutants resistant to inactivation by high hydrostatic pressure. Appl. Environ. Microbiol. 63:945-950.

Hynes, E., J. C. Ogier, and A. Delacroix-Buchet. 2000. Protocol for the manufacture of model washed-curd cheeses under controlled microbiological conditions. Int. Dairy J. 10:733-737. 
Jaquette, C. B., and L. R. Beuchat. 1998. Combined effects of $\mathrm{pH}$, nisin, and temperature on growth and survival of psychrotrophic Bacillus cereus. J. Food Prot. 61:563-570.

Kalchayanand, N., A. Sikes, C. P. Dunne, and B. Ray. 1998. Interaction of hydrostatic pressure, time and temperature of pressurization and pediocin $\mathrm{AcH}$ on inactivation of foodborne bacteria. J. Food Prot. 61:425-431.

Masschalk, B., R. Van Houdt, E. G. R. Van Haver, and C. Michiels. 2001. Inactivation of Gram-negative bacteria by lysozyme, denatured lysozyme and lysozyme derived peptides under high hydrostatic pressure. Appl. Environ. Microbiol. 67:339-344.

McClements, J. M. J., M. F. Patterson, and M. Linton. 2001. The effecth of growth stage and growth temperature on high hydrostatic pressure inactivation of some psychrotrophic bacteria in milk. J. Food Prot. 64:514-522.

Meer, R. R., J. Baker, F. W. Bodyfelt, and M. W. Griffiths. 1991. Psychrotrophic Bacillus spp. in fluid milk products: A review. J. Food Prot. 54:969-979.

Meyer, R. S., K. L. Cooper, D. Knorr, and H. L. M. Lelieveld. 2000. High pressure sterilisation of foods. Food Technol. 54:67-72.

Moerman, F., B. Mertens, L. Demey, and A. Huyghebaert. 2001. Reduction of Bacillus subtilis, Bacillus stearothermophilus, and Streptococcus faecalis in meat batters by temperature-high hydrostatic pressure pasteurisation. Meat Sci. 59:115-125.
Nakayama, A., Y. Yano, S. Kobayashi, M. Ishikawa, and K. Sakai. 1996. Comparison of pressure resistances of spores of six Bacillus strains with their heat resistances. Appl. Environ. Microbiol. 62:3897-3900.

Patterson, M. F., and D. J. Kilkpatrick. 1998. The combined effect of high hydrostatic pressure and mild heat on inactivation of pathogens in milk and poultry. J. Food Prot. 61:432-436.

Raso, J., M. M. Góngora-Nieto, G. V. Barbosa-Cánovas, and B. G. Swanson. 1998. Influence of several environmental factors on the initiation of germination and inactivation of Bacillus cereus by high hydrostatic pressure. Int. J. Food Microbiol. 44:125-132.

Shearer, A. E. H., C. P. Dunne, A. Sikes, and D. G. Hoover. 2000 Bacterial spore inhibition and inactivation in foods by pressure, chemical preservatives, and mild heat. J. Food Prot. 63:15031510 .

Smelt, J. P. P. M. 1998. Recent advances in the microbiology of high pressure processing. Trends Food Sci. Technol. 9:152-158.

Sojka, B., and H. Ludwig. 1994. Pressure-induced germination and inactivation of Bacillus subtilis spores. Pharmaz.Ind. 56:660-663.

Ur-Rehman, S., P. F. Fox, P. L. H. McSweeney, S. A. Madkor, and N. X. Farkye. 2001. Alternatives to pilot plant experiments in cheese-ripening studies. Int. J. Dairy Technol. 54:121-126.

White, C. H. 2000. Testing of milk and milk products. Pages 645680 in Applied Dairy Microbiology. E. H. Marth and J. L. Steele, ed. Marcel Dekker, Inc., New York, NY. 